\title{
Potential antagonistic rhizobacteria to control Colletotrichum scovillei, the cause of anthracnose disease in chili pepper
}

\author{
ANAK AGUNG KETUT DARMADI ${ }^{1}$, DEWA NGURAH SUPRAPTA ${ }^{2, \boldsymbol{v}}$, KHAMDAN KHALIMI ${ }^{2}$ \\ ${ }^{1}$ Department of Biology, Faculty of Mathematics and Natural Sciences, Universitas Udayana. Jl. Raya Bukit Jimbaran, Badung 80361, Bali, Indonesia. \\ ${ }^{2}$ Laboratory of Biopesticide, Faculty of Agriculture, Universitas Udayana. Jl. PB. Sudirman, Denpasar 80238, Bali, Indonesia \\ Tel./fax.: +62-361-255346; ”email: ngurahsuprapta@unud.ac.id
}

Manuscript received: 5 April 2020. Revision accepted: 24 May 2020.

\begin{abstract}
Darmadi AAK, Suprapta DN, Khalimi K. 2020. Potential antagonistic rhizobacteria to control Colletotrichum scovillei, the cause of anthracnose disease in chili pepper. Biodiversitas 21:2727-2734. Six species of Colletotrichum were identified as the cause of anthracnose disease on Bali Island, Indonesia in 2018. These species were C. scovillei, C. acutatum, C. nymphaeae, C. gloesporioides, $C$. truncatum, and $C$. fructicola. Among them, $C$. scovillei was the most prevalent at $55 \%$ of all samples tested. This study was conducted to find potential antagonistic rhizobacteria isolated from various rhizospheres of plants grown in Bali. A total of 1,040 rhizobacteria isolates were tested for their antagonistic activity against the growth of $C$. scovillei on potato dextrose agar. Results showed that 10 isolates inhibited the growth of $C$. scovillei by more than $80 \%$. Among these isolates $\mathrm{C} 1$ and $\mathrm{C} 7 \mathrm{~B}$ possessed inhibitory activity at $94.9 \%$ and $94.3 \%$, respectively. Molecular identification based on analysis of 16S rRNA gene showed that isolate C1 belonged to the species Paenibacillus polymyxa, whereas isolate C7B was identified as Bacillus siamensis. According to scanning electron serious damage on mycelia of $C$. scoville $i$ was observed. Wrinkles were observed on mycelia of $C$. scovillei grown jointly with rhizobacterial isolate $\mathrm{C} 1$, whereas no wrinkle was observed on $C$. scovillei grown solely. Three compounds were detected in the hexane phase of cell-free filtrate $P$. polymyxa $\mathrm{C}$ 1, namely, 3-hydroxy-2-butanone and 2,3-butanediol. These compounds may be responsible for antifungal activity against $C$. scovillei.
\end{abstract}

Keywords: Antagonistic rhizobacteria, anthracnose disease, Colletotrichum scovillei

\section{INTRODUCTION}

Anthracnose disease caused by Colletotrichum spp. was reported to be a serious problem in chili cultivation on Bali Island, Indonesia, with disease incidence of $84 \%$ and disease intensity in the range of $22 \%-78 \%$ (Khalimi et al. 2019). Six species of Colletotrichum, namely C. scovillei, C. acutatum, C. nymphaeae, C. gloesporioides, $C$. truncatum, and $C$. fructicola were identified as the cause of the disease. Among them, $C$. scovillei was the most prevalent at55\% (Khalimi et al. 2019). The disease potentially causes $10 \%-80 \%$ of yield losses depending on cultivation area (Asare-Bediako et al. 2015; Diao et al. 2017; Poonpolgul and Kumphai 2007).

Development of resistant chili cultivar is expected to effectively control the disease, but the resistance against Colletotrichum spp. is often broken down under field conditions (Park 2007). Synthetic fungicides are generally used by farmers to control anthracnose disease, but this measure is not always effective to reduce the disease incidence. Furthermore, the use of synthetic pesticides may have adverse effects on the environment and on the development of resistance against fungicide. This phenomenon was reported by Soesanto (2008), who found out that disease incidence caused by Pythium, Fusarium, and Phytophthora occurred as a result of the use of pentachlorobenzene.

Owing to the increased preference of consumers for organic agricultural products in Indonesia, the organic farming system has become popular among farmers and consumers (Shiotsu et al. 2015). In organic farming biocontrol agents are necessary to manage plant fungal diseases. The use of bio-agents may reduce the use of synthetic chemical fungicides, thereby minimizing adverse effects on the environment. Several bio-agents have been found and reported to possess inhibitory activities against plant pathogens such as Piriformospora indica, Trichoderma viride, Acremonium lolii, and $C$. lindemuthianum against leaf rust of wheat caused by Puccinia recondite (Anwaar et al. 2019). Bacillus cereus SSB1 effectively controlled Pectobacterium infection in potato (Sarfraz et al. 2019), B. amyloliquesfaciens BA-16-8 inhibited the growth of Penicillium expansum, the cause of postharvest decay in apple (Fu et al. 2020).

Among bio-agents that can potentially be used for plant fungal disease control are rhizobacteria, which can colonize plant roots and provide beneficial effects through growth promotion (Saharan and Nehra 2011). Enterobacter cloacae KtB3 isolated from the rhizosphere of groundnut was proven to effectively control damping-off disease on soybean caused by Sclerotium rolfsii (Mahartha and Suprapta 2018). Rhizobacteria are able to produce phytohormones, such as indole acetic acid, ACC deaminase, to fix atmospheric nitrogen, act as antagonistic microbes against plant pathogen through the production of siderophores, $\beta$-1,3-glucanase, chitinase, cellulase, and antibiotics, and are able to dissolve phosphate and other nutrients in the soil (Guo et al. 2015; Saleem et al. 2015; 
Soesanto 2008). For example, Pseudomonas fluorescens produced 2,4-diacetyl phloroglucinol that effectively suppresses plant fungal pathogens (Nowak-Thompson et al. 1994). P. stutzeri produced extracellular chitinase enzyme and laminarinase that can decompose the mycelia of Fusarium solani (Mauch et al. 1988).

Based on the fore mentioned considerations, this study was conducted to find potential antagonistic rhizobacteria that can be used as bio-control agents against anthracnose disease on chili pepper in Bali, Indonesia.

\section{MATERIALS AND METHODS}

\section{Isolation of rhizobacteria}

Isolation of rhizobacteria was conducted from rhizospheres of plants of the Solanaceae, Graminae, and Leguminosae families. First, $10 \mathrm{~g}$ of soil and root of plants from rhizospheres were obtained and diluted in $100 \mathrm{~mL}$ phosphate-buffered saline (PBS). Second, a series of dilutions (until 10-4) was performed using PBS buffer. Cultural medium used for isolation was nutrient agar (NA) medium containing $0.3 \%$ beef extract, $0.5 \%$ peptone, $1.5 \%$ Bacto agar, and distilled water to make $1 \mathrm{~L}$. The medium was added with Nystatin $\left(20 \mathrm{mg} \mathrm{l}^{-1}\right)$ to suppress the growth of fungi. The rhizobacteria colony that appeared from the medium was placed in the NA medium using a wire loop to obtain a single colony. This single colony was then transferred onto slanted NA medium before it was used for further tests.

\section{Selection of rhizobacteria with antifungal activity}

All 540 isolates of rhizobacteria were tested for their antifungal activity against Colletotrichum spp. A colony of rhizobacteria isolates and Colletotrichum was grown side by side at a distance of $2 \mathrm{~cm}$ on potato dextrose agar (PDA) medium in a Petri dish (Pracahyo et al. 2014). All cultures were incubated in the dark for $72 \mathrm{~h}$ under room temperature. In that distance, the Colletotrichum has grown abnormally or inhibition zone was formed, indicating that the rhizobacterial isolate possessed antifungal activity. By contrast, the absence of an inhibition zone indicated no antifungal activity.

\section{Test of antifungal activity level}

Ten isolates of rhizobacteria that showed obvious antifungal activity against $C$. scovillei were tested for the level of their antifungal activity against $C$. scovillei. A method developed by Parwati et al. (2014) was applied in this test. A mycelial plug of $C$. scovillei was placed in the center of the PDA medium on a Petri dish, and then each isolate of rhizobacteria was inoculated on four sides of the fungal colony at $2 \mathrm{~cm}$ distance. For control, a fungal colony without rhizobacteria inoculation was prepared. Ten Petri dishes were prepared for each isolate and control. The cultures were incubated in the dark at a temperature of $28 \pm$ $2^{\circ} \mathrm{C}$. The size of the fungal colony was measured on the third day of incubation using millimeter block paper. Antifungal activity was calculated according to the following formula:

$$
\mathrm{AI}=\frac{\mathrm{C}-\mathrm{T}}{\mathrm{C}} \mathrm{x} 100 \% \text {, }
$$

Where:

AI : antifungal activity (\%)

$\mathrm{C}$ : size of fungal colony on control

$\mathrm{T}$ : size of fungal colony with rhizobacteria treatment

\section{Evaluation of cultural filtrate for antifungal activity}

The antifungal activity of cultural filtrate of isolate $\mathrm{C} 1$ and C7B against C. scovillei was evaluated based on a method developed by Parwati et al. (2014) and Ambaradewi (2012). Each isolate of $\mathrm{C} 1$ and C7B was cultured in potato dextrose broth (PDB) medium. A 300 $\mathrm{mL}$ PDB medium was placed in a $500-\mathrm{mL}$ Erlenmeyer flask and sterilized in an autoclave for $20 \mathrm{~min}$. The $1 \mathrm{~mL}$ each of either $\mathrm{C} 1$ and $\mathrm{C} 7 \mathrm{~B}$ suspension (containing $10^{7} \mathrm{CFU}$ $\mathrm{mL}^{-1}$ ) was inoculated into the PDB medium and incubated in an orbital shaker at $200 \mathrm{rpm}$ for a month. This culture was then subjected to centrifugation at $1000 \mathrm{xg}$ for $15 \mathrm{~min}$. The pellet was discarded and the supernatant was collected and passed through a Millipore membrane with pore size of $0.45 \mu \mathrm{m}$ (Yonezawa Ltd., Japan).

Thereafter, $10 \mathrm{~mL}$ of melted PDA medium was placed in a Petri dish and mixed with $0.5 \mathrm{~mL}$ of spore's suspension of C. scovillei (containing $10^{6}$ spores $/ \mathrm{mL}$ ). After the culture solidified, two diffusion wells were made for every Petri dish using a cork borer (with diameter of $5 \mathrm{~mm}$ ). Into each well, $20 \mu \mathrm{l}$ cell-free filtrate was added; one for cell-free filtrate of isolate $\mathrm{C} 1$ and another for isolate C7B. Sterile PDB broth at the same volume was added into the control wells. The 10 Petri dishes were prepared each for cell-free filtrate treatment and control. The cultures were incubated in the dark at room temperature $\left(28 \pm 2{ }^{\circ} \mathrm{C}\right)$. The diameter of inhibition zone around the diffusion well was measured.

\section{Identification of rhizobacteria isolates based on $16 \mathrm{~S}$ rRNA analysis}

Rhizobacteria isolates were grown in Erlenmeyer flasks containing Tryptic Soy broth media (17 g of Tryptone, $3 \mathrm{~g}$ of Phytone, $5 \mathrm{~g}$ of $\mathrm{NaCl}, 2.5 \mathrm{~g}$ of K2HPO4, and $2.5 \mathrm{~g}$ of glucose, filled up to $1,000 \mathrm{~mL}$ ), incubated for $16 \mathrm{~h}$, and shaken at a speed of $5 \mathrm{x} \mathrm{g}$ at room temperature. Then the rhizobacterial cells were placed in a $2 \mathrm{~mL}$ Eppendorf tube and centrifuged at a speed of $5.000 \mathrm{x} \mathrm{g}$ for $10 \mathrm{~min}$. The supernatant was discarded. Rhizobacteria cells were resuspended with $180 \mu$ l digestion solution, added with $20 \mu \mathrm{l}$ proteinase solution, and mixed until homogeneous by raising the pipette or vortex and incubating at $56^{\circ} \mathrm{C}$ until the tissue was completely lysed (clear liquid was formed). Thereafter, $20 \mathrm{~mL}$ of RNase A solution was added, then vortexed and incubated for $10 \mathrm{~min}$ at room temperature. This mixture was added with $200 \mu$ l lysis solution, and vortexed for $15 \mathrm{~s}$ until the mixture became homogeneous. This mixture was added with $400 \mu \mathrm{l}$ of $50 \%$ ethanol and vortexed. Then, the mixture was transferred to the genomic DNA purification column, which was placed on the collection tube. The column was centrifuged for a minute at $6,000 \mathrm{x}$ g. The collection tube containing the solution was discarded, and the column was placed in the new collection tube and added with $500 \mu \mathrm{l}$ wash buffer I (into which 
ethanol had been added). This mixture was centrifuged for a minute at $8,000 \mathrm{~g}$, the liquid was disposed into the collection tube, and the column was placed back into the collection tube. The mixture was added with $500 \mu 1$ wash buffer II (into which ethanol had been added) into the column and centrifuged for $3 \mathrm{~min}$ at $12,000 \mathrm{x} \mathrm{g}$. If solution residue was left in the column, the collection tube was emptied and the column was centrifuged for a minute at $12,000 \times \mathrm{g}$. The collection tube containing the solution and column was moved to a new $1.5 \mathrm{~mL}$ sterile microtube. Then, $200 \mu \mathrm{l}$ of the elution buffer was added into the middle of the column to dissolve the DNA. This column was incubated for $2 \mathrm{~min}$ at room temperature and centrifuged for $1 \mathrm{~min}$ at $8,000 \mathrm{x} \mathrm{g}$. Then, the column was discarded. Pure DNA was stored at $-20{ }^{\circ} \mathrm{C}$ until it was used for further analysis.

\section{Amplification of DNA by PCR}

The 16S rRNA gene was amplified by PCR using 16S primary pairs (63F 5'-CAG GCC TAA CAC ATG CAA GTC-3 'and 1387R (5'-GGG CGG WGT GTA CAA GGC3'). The reaction was conducted by using a SensoQuest Labcycler with 2x Kapa PCR Ready Mix (Kapa Biosystems, USA), in conditions of $94^{\circ} \mathrm{C}$ for min, followed by 30 consecutive cycles at $94^{\circ} \mathrm{C}$ for $30 \mathrm{~s}, 55^{\circ} \mathrm{C}$ for $45 \mathrm{~s}$, $72^{\circ} \mathrm{C}$ for $2 \mathrm{~min}$, and $72^{\circ} \mathrm{C}$ for $10 \mathrm{~min}$.

\section{S rRNA gene sequencing and DNA sequence analysis}

Nucleotide sequences were determined using an ABI Prism 3100 Avant Genetic Analyzer. Then DNA sequences of the results were trimmed and assembled by using ChromasPro version 1.5. The assembled data were then processed BLAST with data registered with the National Center for Biotechnology Information (NCNI) through the website http://www.ncbi.nlm.nih.gov/BLAST. Some of the BLAST homologous sequence data, which are the closest species, were taken from the GenBank data of NCBI. Then, the data were analyzed again by aligning the sequence using MEGA version 6.0. Furthermore, the data were examined with PAUP 4.0b using maximum parsimony method with 1,000 replication bootstrap. Then, at phylogenetic tree was designed using Tree Graph 2.0 (Stover and Muller 2010).

\section{Ultra-structural responses of $\boldsymbol{C}$. scovillei}

Ultra-structural responses of $C$. scovillei against treatment of cell-free filtrate of Paenibacillus polymyxa C1 were examined through scanning electron microscopy (SEM) according to a method developed by Kawuri et al. (2018) with slight modification. Then, $1 \mathrm{~mL}$ cell-free filtrate of $P$. polymyxa $\mathrm{C} 1$ was placed in Petri dish and then added with $9 \mathrm{~mL}$ melted PDA medium and shaken horizontally to mix the filtrate evenly with PDA. A mycelial plug taken from the edge of $C$. scovillei colony (with diameter of $5 \mathrm{~mm}$ ) was placed in the middle of a Petri dish and then incubated in the dark at $25{ }^{\circ} \mathrm{C}$ for $3 \mathrm{~d}$. Fungal colony on the colony edge was cut into $3 \mathrm{~mm}$ and $1 \mathrm{~mm}$ pieces, followed by the sample preparation process for SEM (JSM-6701F, JEOL, Japan) using an acceleration voltage of $5 \mathrm{kV}$.

\section{GC-MS analysis}

Identification of active compounds in the cell-free filtrate of $P$. polymyxa $\mathrm{C} 1$ was performed using gas chromatography-mass spectroscopy (GC-MS) according to a method developed by Khalimi (2017) with modification. A 50-mL cell-free cultural filtrate of $P$. polymyxa $\mathrm{C} 1$ was added with $50 \mathrm{~mL}$ hexane (PA grade), mixed thoroughly, and placed in a separating funnel. The water and hexane phases were collected separately and the hexane phase was evaporated in a vacuum rotary evaporator (Iwaki, Japan) until the volume was approximately $10 \mathrm{~mL}$. This hexane phase proceeded for GC-MS analysis (QP 2010 Shimadzu, Japan). Liquid nitrogen was used as elution solvent with flow rate of $1 \mathrm{~mL} / \mathrm{min}$ on a Wakosil ODS/5c18-200 column under temperature of $250{ }^{\circ} \mathrm{C}$. Then, UV light at a length of $254 \mathrm{~nm}$ was used for detection and matched with identified compounds in the GC-MS library.

\section{RESULTS AND DISCUSSION}

\section{Isolates with antifungal activity against $\boldsymbol{C}$. scovillei}

A total of 540 isolates of rhizobacteria were obtained in this study and tested for their antifungal activity against $C$. scovillei. Then, 10 isolates of rhizobacteria showed obvious antifungal activity against $C$. scovillei as shown in Table 1. All 10 isolates of rhizobacteria showed over $80 \%$ inhibitory activity and among them, the $\mathrm{C} 1$ and $\mathrm{C} 7 \mathrm{~B}$ isolates exhibited antifungal activity at $94.9 \%$ and $94.3 \%$, respectively. Based on this result, these two isolates were used for further tests.

\section{Antifungal activity of cell-free filtrate}

Clear zones (inhibition zone) around the wells filled with cell-free filtrates of isolates $\mathrm{C} 1$ and $\mathrm{C} 7 \mathrm{~B}$ were formed as shown in Fig. 1. The average diameter of the inhibition zones was $18.7 \pm 1.1 \mathrm{~mm}$ and $17.4 \pm 1.3 \mathrm{~mm}$, respectively, for isolates $\mathrm{C} 1$ and $\mathrm{C} 7 \mathrm{~B}$ as presented in Table 2. This result revealed that both isolates produced antifungal substances that inhibited the growth of C. scovillei.

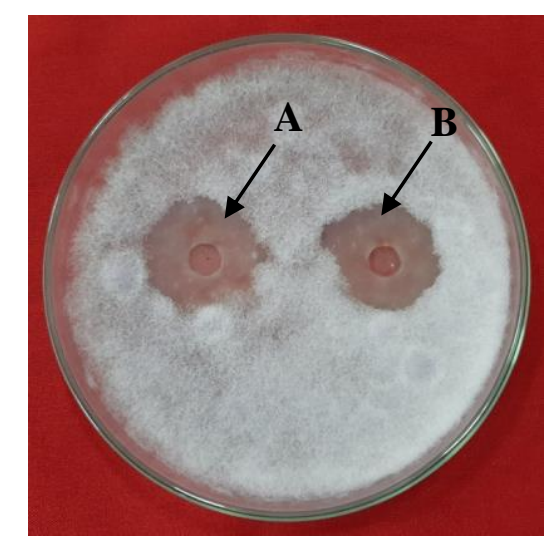

Figure 1. Inhibition zones formed around the wells filled with cell-free filtrates of (A) isolate C1 and (B) C7B on PDA medium inoculated with Colletotrichum scovillei. Arrows indicate the inhibition zones 


\title{
Species of rhizobacteria
}

Based on analysis of the genes of $16 \mathrm{~S}$ rRNA, the sequence of isolate $\mathrm{C} 1$ is as follows:

\begin{abstract}
CGGCGGCTGGCTCCTTGCGGTTACCTCACCGACTTCGGGTGTTGTAAACTCTCGTGGTGT GACGGGCGGTGTGTACAAGACCCGGGAACGTATTCACCGCGGCATGCTGATCCGCGATTA CTAGCAATTCCGACTTCATGTAGGCGAGTTGCAGCCTACAATCCGAACTGAGACCGGCTT TTCTAGGATTGGCTCCACATCGCGGCTTCGCTTCCCGTTGTACCGGCCATTGTAGTACGT GTGTAGCCCAGGTCATAAGGGGCATGATGATTTGACGTCATCCCCACCTTCCTCCGGTTT GTCACCGGCAGTCTGCTTAGAGTGCCCAGCTTGACCTGCTGGCAACTAAGCATAAGGGTT GCGCTCGTTGCGGGACTTAACCCAACATCTCACGACACGAGCTGACGACAACCATGCACC ACCTGTCTCCTCTGTCCCGAAGGAAAGGYCTATCTCTAGACCGGTCAGAGGGATGTCAAG ACCTGGTAAGGTTCTTCGCGTTGCTTCGAATTAAACCACATACTCCACTGCTTGTGCGGG TCCCCGTCAATTCCTTTGAGTTTCAGTCTTGCGACCGTACTCCCCAGGCGGAATGCTTAA TGTGTTAACTTCGGCACCAAGGGTATCGAAACCCCTAACACCTAGCATTCATCGTTTACG GCGTGGACTACCAGGGTATCTAATCCTGTTTGCTCCCCACGCTTTCGCGCCTCAGCGTCA GTTACAGCCCAGAGAGTCGCCTTCGCCACTGGTGTTCCTCCACATCTCTACGCATTTCAC CGCTACACGTGGAATTCCACTCTCCTCTTCTGCACTCAAGCTCCCCAGTTTCCAGTGCGA CCCGAAGTTGAGCCTCGGGATTAAACACCAGACTTAAAGAGCCGCCTGCGCGCGCTTTAC GCCCAATAATTCCGGACAACGCTTGCCCCCTACGTATTACCGCGGCTGCTGGCACGTAGT TAGCCGGGGCTTTCTTCTCAGGTACCGTCACTCCTATAGCAGTTACTCTACAAGACGTTC TTCCCTGGCAACAGAGCTTTACGATCCGAAAACCTTCATCACTCACGCGGCGTTGCTCCG TCAGGCTTTCGCCCATTGCGGAAGATTCCCTACTGCTGCCTCCCGTAGGAGTCTGGGCCG TGTCTCAGTCCCAGTGTGGCCGATCACCCTCTCAGGTCGGCTACGCATCGTCGCCTTGGT AGGCCTTTACCCCACCAACTAGCTAATGCGCCGCAGGCCCATCCACAAGTGACAGATTGC TCCGCCTTTCCTCCTTCTCCCATGCAGGAAAAGGATGTATCGGGTATTAGCTACCGTTTC CGGTAGTTATCCCTGTCTTGTGGGCAGGTTGCCTACGTGTTACTCACCCGTCCGCCGCTA GGTTAATTAGAAGCAAGCTTC
\end{abstract}

Analytical result of $16 \mathrm{~S}$ rRNA gene of isolate C7B is as follows:

GGCGGCTGGCTCCATAAAGGTTACCTCACCGACTTCGGGTGTTACAAACTCTCGTGGTGT GACGGGCGGTGTGTACAAGGCCCGGGAACGTATTCACCGCGGCATGCTGATCCGCGATTA CTAGCGATTCCAGCTTCACGCAGTCGAGTTGCAGACTGCGATCCGAACTGAGAACAGATT TGTGGGATTGGCTTAACCTCGCGGTTTCGCTGCCCTTTGTTCTGTCCATTGTAGCACGTG TGTAGCCCAGGTCATAAGGGGCATGATGATTTGACGTCATCCCCACCTTCCTCCGGTTTG TCACCGGCAGTCACCTTAGAGTGCCCAACTGAATGCTGGCAACTAAGATCAAGGGTTGCG CTCGTTGCGGGACTTAACCCAACATCTCACGACACGAGCTGACGACAACCATGCACCACC TGTCACTCTGCCCCCGAAGGGGACGTCCTATCTCTAGGATTGTCAGAGGATGTCAAGACC TGGTAAGGTTCTTCGCGTTGCTTCGAATTAAACCACATGCTCCACCGCTTGTGCGGGCCC CCGTCAATTCCTTTGAGTTTCAGTCTTGCGACCGTACTCCCCAGGCGGAGTGCTTAATGC GTTAGCTGCAGCACTAAGGGGCGGAAACCCCCTAACACTTAGCACTCATCGTTTACGGCG TGGACTACCAGGGTATCTAATCCTGTTCGCTCCCCACGCTTTCGCTCCTCAGCGTCAGTT ACAGACCAGAGAGTCGCCTTCGCCACTGGTGTTCCTCCACATCTCTACGCATTTCACCGC TACACGTGGAATTCCACTCTCCTCTTCTGCACTCAAGTTCCCCAGTTTCCAATGACCCTC CCCGGTTGAGCCGGGGGCTTTCACATCAGACTTAAGAAACCGCCTGCGAGCCCTTTACGC CCAATAATTCCGGACAACGCTTGCCACCTACGTATTACCGCGGCTGCTGGCACGTAGTTA GCCGTGGCTTTCTGGTTAGGTACCGTCAAGGTGCCGCCCTATTTGAACGGCACTTGTTCT TCCCTAACAACAGAGCTTTACGATCCGAAAACCTTCATCACTCACGCGGCGTTGCTCCGT CAGACTTTCGTCCATTGCGGAAGATTCCCTACTGCTGCCTCCCGTAGGAGTCTGGGCCGT GTCTCAGTCCCAGTGTGGCCGATCACCCTCTCAGGTCGGCTACGCATCGTCGCCTTGGTG AGCCGTTACCTCACCAACTAGCTAATGCGCCGCGGGTCCATCTGTAAGTGGTAGCCGAAG CCACCTTTTATGTCTGAACCATGCGGTTCAGACAACCATCCGGTATTAGCCCCGGTTTCC CGGAGTTATCCCAGTCTTACAGGCAGGTTACCCACGTGTTACTCACCCGTCCGCCGCTAA CATCAGGGAGCAAGCTCCCATCTGTCCGCTCGA 


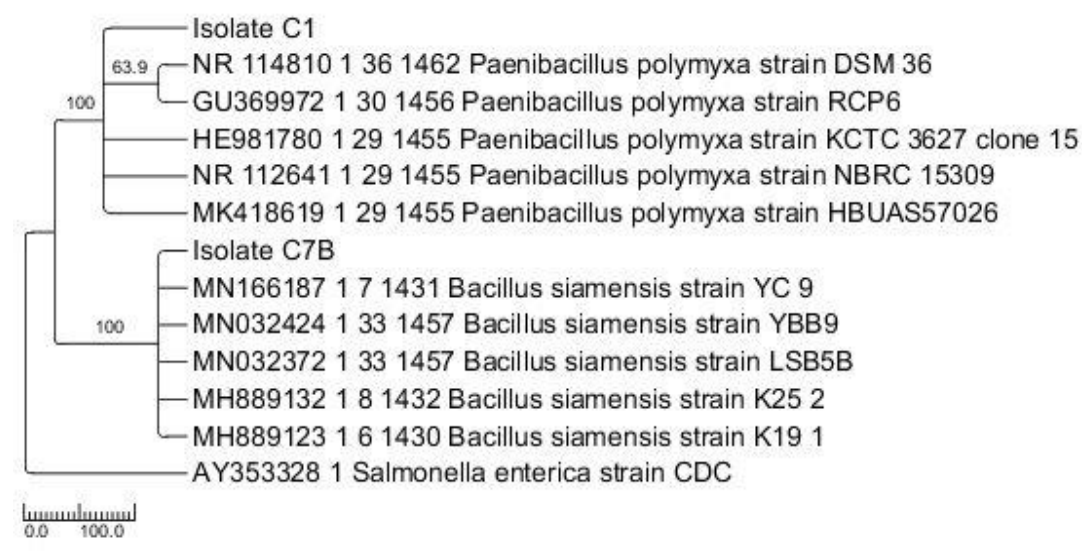

Figure 2. Phylogenetic relationship tree of isolates C1 and C7B with 14 isolates of bacteria based on 16S rRNA gene using maximum parsimony method

Table 1. Level of antifungal activity of 10 isolates of rhizobacteria against Colletotrichum scovillei

\begin{tabular}{llc}
\hline $\begin{array}{c}\text { Name of } \\
\text { isolate }\end{array}$ & \multicolumn{1}{c}{ Sampling sites } & $\begin{array}{c}\text { Antifungal activity } \\
\text { against } \boldsymbol{C} \text {. scovillei } \\
(\%) \pm \text { deviation } \\
\text { standard }\end{array}$ \\
\hline ORPg7 & Pegok, Denpasar & $83.2 \pm 3.7$ \\
GbBd35 & Ungasan, Badung & $83.2 \pm 2.9$ \\
GbBd68 & Ungasan, Badung & $81.2 \pm 4.3$ \\
SuB145 & Suter, Bangli & $80.6 \pm 4.7$ \\
Cl & Kedisan, Bangli & $94.9 \pm 3.8^{*}$ \\
GgSg13 & Gerokgak, Buleleng & $80.2 \pm 3.5$ \\
KsSg12 & Kalisada, Buleleng & $84.6 \pm 5.7$ \\
MjSg42 & Menjangan, Buleleng & $81.2 \pm 4.8$ \\
C7B & TNBB, Jembrana & $94.3 \pm 4.2 *$ \\
TNJb36 & TNBB, Jembrana & $80.6 \pm 3.2$ \\
\hline
\end{tabular}

Note: $*$ These isolates were processed for identification

Table 2. Average size of inhibition zones formed around the wells filled with cell-free filtrates of isolate $\mathrm{C} 1$ and $\mathrm{C} 7 \mathrm{~B}$.

\begin{tabular}{lc}
\hline Isolate & $\begin{array}{c}\text { Diameter of inhibition zones }(\mathbf{m m}) \\
\mathbf{\pm} \text { standard deviation }\end{array}$ \\
\hline $\mathrm{C} 1$ & $18.7 \pm 1.1^{*}$ \\
$\mathrm{C} 7 \mathrm{~B}$ & $17.4 \pm 1.3$ \\
\hline Note: * Average of 10 replicates
\end{tabular}

Based on the alignment of $16 \mathrm{~S}$ rRNA gene with database in GenBank using BlastN program, isolate $\mathrm{Cl}$ belongs to the $P$. polymyxa group because this isolate is homologous with bacteria in the GenBank data-base with the maximum percentage of similarity by $99.71 \%$, as shown in Table 3 and Fig. 2. For isolate C7B which belongs to the Bacillus siamensis group because this isolate is homologous with bacteria in the GenBank database with $100 \%$ maximum percentage of similarity, as shown in Table 4 and Fig. 2.

\section{Ultra-structural response of $S$. scovillei}

Scanning electron microscopy showed that serious damage on the mycelia of $C$. scovillei was observed. Wrinkles were observed on the mycelia of $C$. scovillei grown side by side with $P$. polymyxa $\mathrm{C} 1$, whereas no such wrinkle was observed on $C$. scovillei grown solely, as exhibited in Fig. 3.

\section{Compounds in cell-free filtrate of $P$. polymyxa}

Based on analysis using gas chromatography-mass spectroscopy (GC-MS), three peaks were detected in the cell-free filtrate of $P$. polymyxa $\mathrm{C} 1$ with retention times of $2.260,2.925$, and 3.077 , respectively for peaks 1,2 , and 3 (Fig. 4). These compounds were identified as butanediol with peak area of $3.44 \%$ (peak 3), as presented in Table 5 .

Table 3. Similarity of 16S rRNA gene of isolate $\mathrm{C} 1$ with sequences of DNA in GenBank using BlastN program

\begin{tabular}{lcc}
\hline Species of bacteria in GenBank & Percentage of similarity & Accession number \\
\hline P. polymyxa strain JSa-9 16S ribosomal gene partial sequence & 99.71 & EU882855.1 \\
P.polymyxa partial 16S rRNA gene strain KCTC3627 & 99.64 & HE981790.1 \\
P.polymyxa isolate TN76 16S rRNA gene partial sequence & 99.64 & EU362604.1 \\
P. polymyxa strain DSM 36 16S rRNA partial gene sequence & 99.64 & NR 114810.1 \\
P. polymyxa strain RCP6 16S rRNA gene partial sequence & 99.57 & GU369972.1 \\
P. polymyxa strain NRBC 15309 16S rRNA gene partial sequence & 99.50 & NR 112641.1 \\
P. polymyxa strain IAM 13419 16 S rRNA gene partial sequence & 99.50 & NR 112117.1 \\
\hline
\end{tabular}


Table 4. Similarity of 16S rRNA gene of isolate C7B with sequences of DNA in GenBank using BlastN program

\begin{tabular}{lcc}
\hline Species of bacteria in GenBank & Percentage of similarity & Accession number \\
\hline B. siamensis strain YC-9 16S ribosomal RNA gene partial sequence & 100 & MN166187.1 \\
B. siamensis strain YBB9 16S ribosomal RNA gene partial sequence & 100 & MN042424.1 \\
B. siamensis strain LSB5B 16S ribosomal RNA gene partial sequence & 100 & MN032372.1 \\
B. siamensis strain LSB5A 16S ribosomal RNA gene partial sequence & 100 & MN032371.1 \\
B. siamensis strain NSB5 16S ribosomal RNA gene partial sequence & 100 & MN032365.1 \\
\hline
\end{tabular}

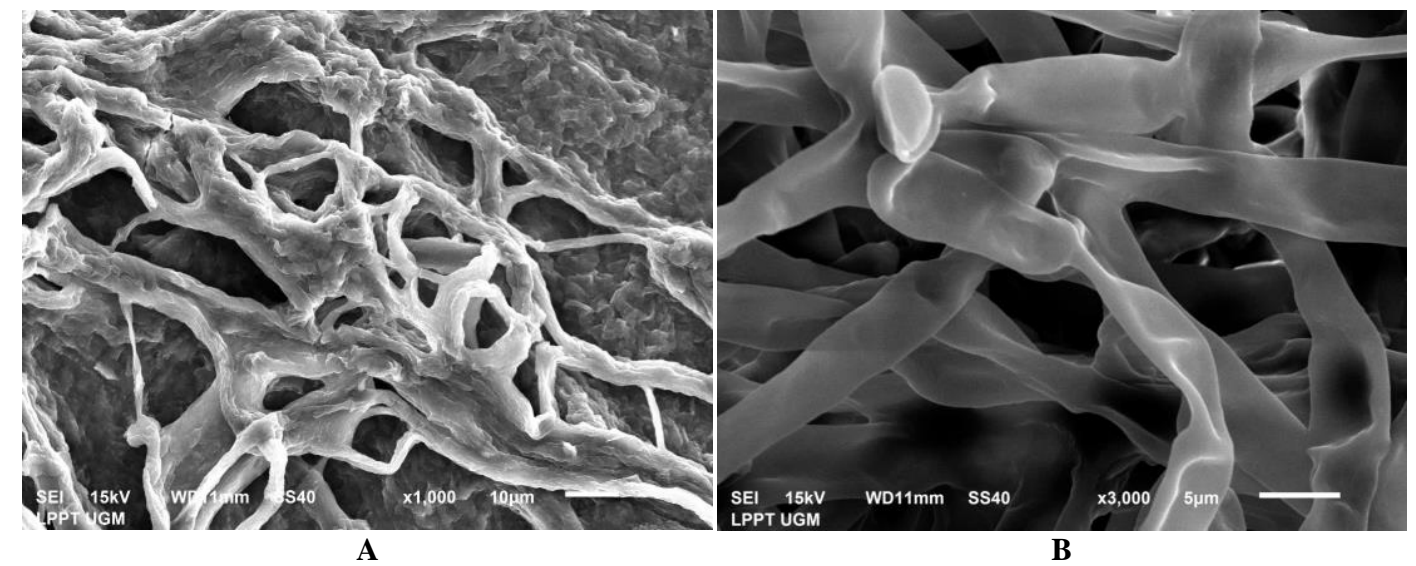

Figure 3. Scanning electron micrographs of mycelia of Colletotrichum scovillei treated with Paenibacillus polymyxa C1 (A) and control (B)

Table 5. Compounds detected in cell-free filtrate of Paenibacillus polymyxa $\mathrm{C} 1$

\begin{tabular}{cccc}
\hline $\begin{array}{c}\text { Peak } \\
\text { number }\end{array}$ & $\begin{array}{c}\text { Retention } \\
\text { time } \\
\text { (minutes) }\end{array}$ & Name of compound & $\begin{array}{c}\text { Peak area } \\
(\boldsymbol{\%})\end{array}$ \\
\hline 1 & 2.260 & 3-hydroxy-2-butanone & 5.62 \\
2 & 2.925 & 2,3-butanediol & 23.51 \\
3 & 3.077 & 2,3-butanediol & 3.44 \\
\hline
\end{tabular}

\section{Discussion}

In our present study, we found two isolates of local rhizobacteria, namely, $P$. polymyxa $\mathrm{C} 1$ and $B$. siamensis $\mathrm{C} 7 \mathrm{~B}$, which showed strong antifungal activity against $C$. scovillei, the prominent cause of anthracnose disease on chili pepper in Bali, Indonesia. Both of these isolates inhibited the growth of $C$. scovillei on the PDA medium.

Several species of microbes have been tested and showed antifungal activities against plant fungal pathogens, and some of them have been successfully controlled plant fungal diseases of important agricultural crops (AdameGarcia et al. 2016; Guo et al. 2015; Hudge 2015; Parwati et al. 2014; Suprapta 2012; Suprapta et al. 2014a; Widnyana et al. 2013).
Antagonism between rhizobacteria and plant fungal pathogens may have happened through antibiosis, parasitism, predation, competition, production of extracellular enzymes, and induced resistance (Zhang 2004). E. cloacae EcCT -501 was reported to have effectively suppressed the damping-off disease on cucumber through the production of siderophore hydroxamate, aerobactin, and catechol (Costa and Loper 1993). E. cloacae subsp. cloacae ENHKU01 was also reported to possess antagonistic activity against Colletotrichum capsici, Sclerotinia sclerotiorum, Alternaria sp., Didymella bryoniae, and Fusarium oxysporum under in vitro condition by producing chitinase enzyme, siderophore aerobactin, and enterobactin (Liu et al. 2013). Vibrio sp. R-10 produced siderophore amphibactin that acts as an antifungal substance (Martinez et al. 2003). Burkholderia sp. strain MSSP produced hydroxymethyl-chroman-4-one that acts as an antifungal against Pythium ultimum, Phytophthora capsici, and Sclerotinia sclerotiorum (Kang et al. 2004).

Another study showed that E. agglomerans Al7Kla effectively reduced the intensity of blast disease on rice caused by Pyricularia oryzae (Suprapta et al. 2014a), whereas E. cloacae Gg14D was reported to be plantgrowth-promoting rhizobacteria, without antifungal activity (Suprapta et al. 2014b). 


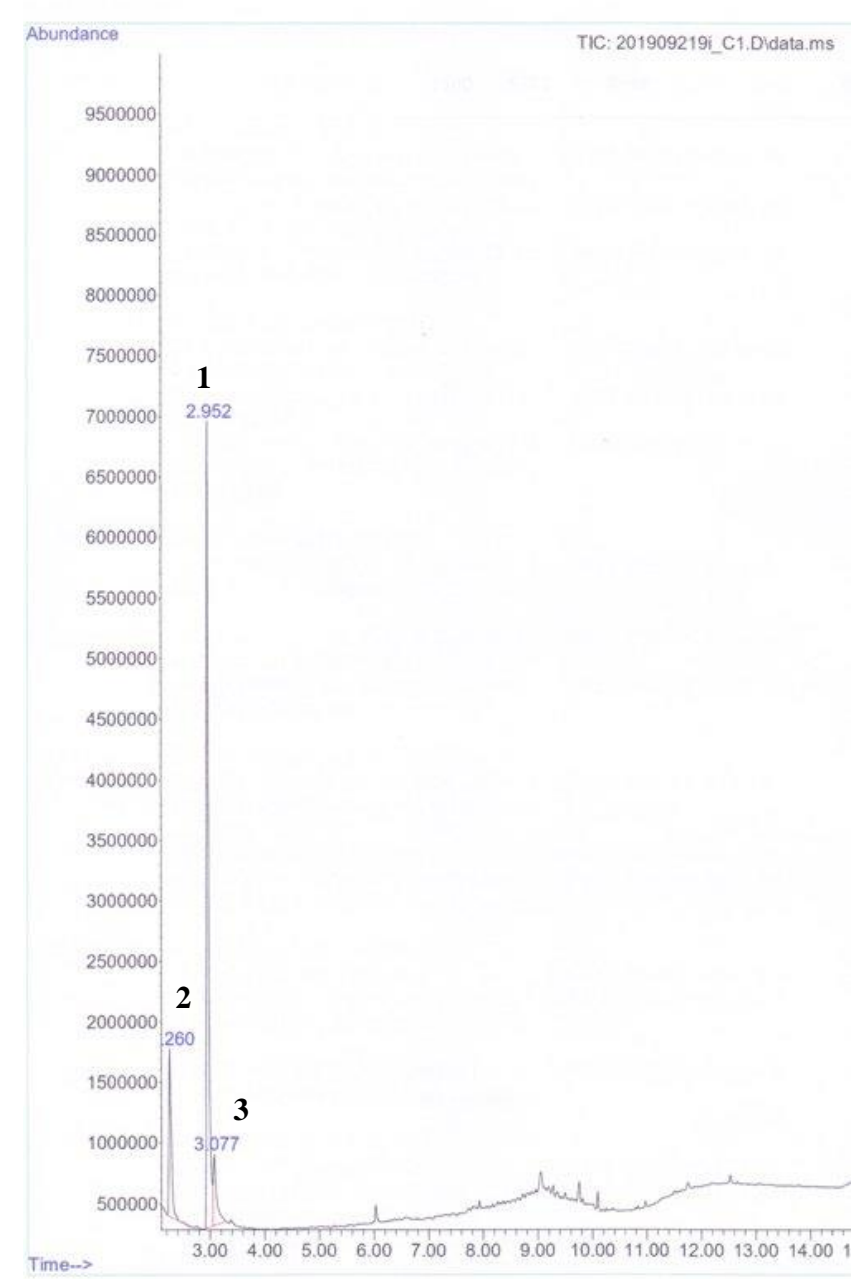

Figure 4. Chromatograms of compounds produced by Paenibacillus polymyxa C1 using GC-MS

In the present study, we detected three compounds in the cell-free filtrate of $P$. polymixa $\mathrm{C} 1$, namely, 3-hydroxy2-butanone; 2,3-butanediol, and 2,3-butanediol. These compounds may be responsible for the antifungal activity of $P$. polymyxa $\mathrm{C} 1$ against $C$. scovillei. Total peak areas of 2,3-Butanediol (compound numbers 2 and 3 in Fig. 4 and Table 5) was 26.95\%, whereas that for 3-hydroxy-2butanone (compound 1) was only $5.62 \%$. However, further study is needed to identify the compound that contributed dominantly to antifungal activity. Other researchers proved that 3-hydroxy-2-butanone is one of the volatile compounds with antifungal activity (Lim et al. 2017). Arrebola et al. (2010) also proved that 3-hydroxy-2butanone is one of the volatile compounds with antifungal activity against Penicillium crustosum. A compound 2,3butanediol extracted from $P$. polymyxa culture was proven to induce systemic acquired resistance against Phytophthora parasitica var. nicotianae (Park et al. 2018).

In conclusion, two species of local rhizobacteria, namely, $P$. polymyxa $\mathrm{C} 1$ and $B$. siamensis $\mathrm{C} 7 \mathrm{~B}$, were first reported to have effectively inhibited the growth of $C$. scovillei, the cause of anthracnose disease on chili pepper in Bali. The cell-free cultural filtrates of both isolates inhibited the growth of C. Scovillei. P. polymyxa $\mathrm{C} 1$ caused wrinkles on mycelia of $C$. scovillei. Two types of compounds were detected in the cell-free filtrate of $P$. polymyxa $\mathrm{C} 1$ namely 3-hydroxy-2-butanone and 2,3butanediol. These compounds may be responsible for the antifungal activity against $C$. scovillei. $P$. polymyxa $\mathrm{C} 1$ can be considered as a potential bio-agent to control anthracnose disease on chili pepper in Bali. Further study and field tests are necessary to develop a $P$. polymyxa $\mathrm{C} 1$ formula that can be used in a green-house.

\section{ACKNOWLEDGEMENTS}

The authors grateful to the Institute of Research and Community Services, Udayana University, for providing the research grant in fiscal year 2019 under the Penelitian Percepatan Guru Besar scheme. High appreciations are sent to Dr. Fumitaka Shiotsu of Meiji University, Japan, and Dr. Azwan Mat Lazim of Universiti Kebangsaan Malaysia for valuable comments and suggestions to improve this paper.

\section{REFERENCES}

Adame-Garcia J, Luna-Rodriguez M, Iglesias-Andreu LG. 2016. Vanilla rhizobacteria as antagonists against Fusarium oxysforum f.sp. vanillae. Intl J Agric Biol 18: 23-30.

Anwaar HA, Ali S, Sahi ST, Siddiqui MT. 2019. Evaluating the antagonistic role of fungal endophytes against leaf rust of wheat caused by Puccinia recondita. Intl J Agric Biol 21: 333-337.

Arrebola E, Sivakumar D, Korsten L. 2010. Effect of volatile compounds produced by Bacillus strains on postharvest decay in citrus. Biol Control 53: 122-128.

Asare-Badiako E, Addo-Quaye A, Boakye B, Sarbah JM, Asante P, Dorm E. 2015. Incidence and severity of viral and fungal diseases of Chili pepper (Capsicum frutescens) in some districts in Chana. Intl J Plant Soil Sci 1: 147-159.

Costa JM, Loper JE. 1993. Characterization of Siderophore Production by the Biological Control Agent Enterobacter cloacae. Mol PlantMicrob Interact 7: 440-448.

Diao YZ, Zhang C, Liu F, Wang WZ, Liu L, Cai L, Liu XL. 2017. Colletotrichum species causing anthracnose disease of chili in China. Persoonia 38: 20-37.

Fu R, Zhang H, Chang H, Zhang F, Chen W. 2020. Evaluation of antifungal mechanism of Bacillus amyloliquefaciens BA-16-8. Intl J Agric Biol 23: 405-408.

Guo JH, Jiang CH, Xie P, Huang ZY, Fa ZH. 2015. The plant health and safety guards plant growth-promoting rhizobacteria (PGPR). Transcriptomics 3: 109. Doi: 10.4172/2329-8936.1000109.

Hudge BV. 2015. Management of damping-off disease on soybean caused by Pythium ultimum Trow. Intl J Curr Microbiol App Sci 4: 799-808.

Kang JG, Shin SY, Kim MJ, Bajpai V, Maheshwari DK, Kang SC. 2004. Isolation and Anti-fungal Activities of 2-Hydroxymethyl-chroman-4one Produced by Burkholderia sp. MSSP. J Antibiot 57 : 726-731.

Kawuri R, Suprapta DN, Nitta Y. 2018. Antagonistic activity of Streptomyces thermocarboxydus to Fusarium oxysporum the cause of leaf rot disease on Aloe vera (Aloe barbadensis Mill.) in Bali. Malays J Microbiol 14: 10-15.

Khalimi K. 2017. The use of rhizobacteria as bio-stimulant to increase the quantity and quality of Edamame (Glycine mas L. Merrill). [Dissertation]. Faculty of Agriculture Udayana University, Denpasar Bali. [Indonesian]

Khalimi K, Darmadi AAK, Suprapta DN. 2019. First Report on the Prevalence of Colletotrichum scovillei Associated with Anthracnose on Chili Pepper in Bali, Indonesia. Intl J Agric Biol 22: 363-368. 
Lim SM, Yoon MY, Choi GJ, Choi YH, Jang KS, Shin TS, Park HW, Yu NH, Kim YH, Kim JC. 2017. Diffusible and volatile antifungal compounds produced by an antagonistic Bacillus vezelensis $\mathrm{G} 341$ against various phytopathogenic fungi. Plant Pathol J 33: 488-498.

Liu WY, Wong CF, Chung KMK, Jiang JW, Leung FCC. 2013. Comparative Genome Analysis of Enterobacter cloacae. PLoS ONE 8 (9): e74487. DOI: 10.1371/journal.pone.0074487.

Mahartha KA, Suprapta DN. 2018. Efficacy of Enterobacter cloacae KtB3 to control damping-off disease on soybean caused by Sclerotium rolfsii. Intl J Agric Biol 20: 871-876.

Martinez JS, Carter-Franklin JN, Mann EL, Martin JD, Haygood MG, Butler A. 2003. Structure and membrane affinity of a suite of amphiphilic siderophores produced by a marine bacterium. Proc Natl Acad Sci USA 100: 3754-3759.

Mauch F, Mauch-Mani B, Boller T. 1988. Antifungal hydrolases in pea tissue. II. Inhibition of fungal growth by combinations of chitinase and 3-1,3 glucanase. Plant Physiol 88: 936-942.

Nowak-Thompson B, Gould SJ, Kraus J, Loper JE. 1994. Production of 2,4-diacetylphloroglucinol by the biocontrol agent Pseudomonas fluorescens Pf-5. Can J Microbiol 40: 1064-1066.

Park HG. 2007. Problems of anthracnose in pepper and prospects for its management. In: Oh DG, Kim KT (eds.) Abstracts of the First International Symposium on Chilli Anthracnose. National Horticultural Research Institute, Rural Development of Administration, Seoul, Republic of Korea.

Park KY, Seo SY, Oh BR, Seo JW, Kim YJ. 2018. 2,3-butanediol induces systemic acquired resistance in the plant immune response. J Plant Biol 61: 424-434.

Parwati GAKC, Khalimi K, Adiartayasa W. 2014. Efficacy test of Pantoea agglomerans GTA24 formulation in controlling damping-off disease on soybean caused by Sclerotium rolfsii. Agroekoteknologi Tropika 3: 218-229. [Indonesian]

Poonpolgul S, Kumphai S. 2007. Chilli Pepper Anthracnose in Thailand Country Report. In: Oh DG, Kim KT (eds.) Abstracts of the First International Symposium on Chili Anthracnose. National Horticultural Research Institute, Rural Development of Administration, , Seoul, Republic of Korea.
Pracahyo R, Khalimi K, Wijana G. 2014. Potential of bacand biostimulant on rice plant. Agroekoteknologi Tropika 3: 232-241. [Indonesian]

Saleem AR, Bangash N, Mahmood T, Khalid A, Centritto M, Siddique MT. 2015. Rhizobacteria capable of producing ACC deaminase promote growth of velvet bean (Mucuna pruriens) under water stress conditions. Intl J Agric Biol 17: 663-667.

Saharan BS, Nehra V. 2011. Plant Growth Promoting Rhizobacteria: A Critical Review. LSMR 21: 1-30.

Sarfraz S, Sahi ST, Ali MA, Khan SH, Faure D. 2019. Antagonistic potential of N-acyl-homoserine lactone degrading Bacillus species for controlling Pectobacterium based infections in potato. Intl J Agric Biol 22: 639-646.

Shiotsu F, Sakagami N, Asagi N, Suprapta DN, Agustiani N, Nitta Y, Komatsuzaki M. 2015. Initiation and dissemination of organic rice cultivation in Bali, Indonesia. Sustainability 7: 5171-5181.

Soesanto L. 2008. Introduction to biological control of plant diseases. Raja Grafindo Persada, Jakarta. [Indonesian]

Stover BC, Muller KF. 2010. TreeGraph 2: combining and visualizing evidence from different phylogenetic analyses. BMC Bioinformatics 11: 7. DOI: $10.1186 / 1471-2105-11-7$.

Suprapta DN. 2012. Potential of microbial antagonists as biocontrol agents against plant fungal pathogens. J ISSAAS 18: 1-18.

Suprapta DN, Quintao V, Khalimi K. 2014a. Effectiveness of rhizobacteria to reduce rice blast disease intensity. J Biol Agric Healthcare 4: 35-41.

Suprapta DN, Maulina NMI, Khalimi K. 2014b. Effectiveness of Enterobacter cloacae to promote the growth and increase the yield of rice. J Biol Agric Healthcare 4: 44-50.

Widnyana IK, Suprapta DN, Sudana IM, Temaja IGRM. 2013. Pseudomonas alcaligenes, potential antagonist against Fusarium oxysporum f.sp. lycopersici the cause of Fusarium wilt disease on tomato. J Biol Agric Healthcare 3: 163-169.

Zhang Y. 2004. Biocontrol of Sclerotinia Stem Rot of Canola by Bacterial Antagonists and Study of Biocontrol Mechanisms Involved. [Dissertation]. University of Manitoba, Canada. 